Egyptian J. of Nutrition Vol. XXXIV No. 2 (2019)

\title{
Ameliorate the effect of camel milk on obesity in male albino rats
}

\author{
Abdel-Mobdy, A. $E^{(1)}$; Amall. Abdel-Mohsin (2), Aly, H. $E^{(2)}$ \\ and Abdel-.Rahim, E. A. ${ }^{(3)}$ \\ (1) Dairy Sci. Dept., Fac. Agric., Cairo Univ., Giza Egypt \\ (2)Dairy Chem. Dept., Animal Prod. Res.Inst., (A.R.C.), \\ Dokki Giza Egypt \\ ${ }^{(3)}$ Biochem. Dept., Fac. Agric., Cairo Univ., Giza Egypt.
}

\begin{abstract}
Obesity (Hyperlipidemia) is a medical condition characterized by an increase in one or more of the plasma lipids, including triglycerides, cholesterol, cholesterol esters, phospholipids and or plasma lipoproteins such as very low-density lipoprotein (vLDL-c) and low-density lipoprotein (LDL-c) along with reduced high-density lipoprotein (HDL-c) levels. The nutritional values of the camel milk were determined. The present study was designed to explore the efficiency of camel milk in controlling hyperlipidemia . 25 male albino rats were used in this investigation which divided into five groups.
\end{abstract}

The first one was used as a normal health control group (G1), while the remaining four groups were feeding with high-fat diet in order to induce hyperlipidemia (obesity). The hyperlipidemic group was divided into hyperlipidemia control group (G2), the other groupshyperlipidemic rats treated with camel milk according to the amount of $1 \mathrm{ml}(\mathrm{G} 3), 1.5 \mathrm{ml}(\mathrm{G} \mathrm{4})$ and $2 \mathrm{ml}$ (G 5), and the period of the treatments was for 7 weeks. Body weight gain and feed efficiency 


\section{Abdel-Mobdy, A. E, Amall. Abdel-Mohsin, Aly, H. E and Abdel-.Rahim, E. A.}

were determined blood lipid profile, liver function and kidneys function as well as blood glucose content and LDH activity were measured also.

The results of the present study revealed that there were significant improvements for hyperlipidemictreated groups in comparison with thatgroup without any treatment. The camel milk group exhibited a significant amelioration in lipid profile compared to hyperlipidemia control animals. This study documented the efficiency of the camel milk in controlling of hyperlipidemia and improvement of kidneys function and liver function. Also the using of camel milk in the treatments alleviated the disturbance of obesity and produced a desirable influences for body weight gain in obesity animal.It can be concluded that camel milk can used to attenuate the hyperlipidemic, hypercholesterolemic and obesity harmful.

It has been found that the measurements of treated groups approach the healthy group depending on the following from increasing to decreasing order:

camel milk $(2 \mathrm{ml}) \leq$ camel milk $(1.5 \mathrm{ml})<$ camel milk $(1 \mathrm{ml})$

\section{Introduction}

Hypercholesterolemia is a significant risk factor for atherosclerosis, which is related to coronary heart disease. It is a condition where abnormally high levels of lipids are found especially low density lipoproteins cholesterol (LDL-C), cholesterol and triglycerides in the blood and leads to hyperlipidemia. This condition is also called hyperlipoproteinemia. In fact, human body is complex machinery and any undesirable change will disturb the balance 
Egyptian J. of Nutrition Vol. XXXIV No. 2 (2019)

resulting in diseased state (Gupta,2011 and Kopparapu,2011). Hypercholesterolemia may be responsible for oxidative modification of LDL-c, protein glycation, glucose-auto-oxidation with excess production of free radicals and lipid peroxidation products, which represent major risk factors for ischemic heart diseases (Olorunnisola et al.,2012).

Hyperlipidemic associated with profound variations in plasma lipids profile and lipoprotein profile, and is responsible for vascular complications and an increased risk of heart disease (Fontbonne et al., 1989 and Motta et al., 2001). Thus, lowering the cholesterol levels through dietary or drug therapy seems to be associated with a reduced risk of heart disease (Grundy et al., 1999).

Low-density lipoprotein-c (LDL-c) in the human body circulation undergoes reuptake in the liver through particular receptors and is thereby cleared from the circulation (Lusis, 2000). The elevation of LDL-c levels in the plasma of diabetic patients can be the result of a defect in the LDL-c receptor (i.e., failure in production or function). High-density lipoprotein-c (HDL-c) is protective by reversing cholesterol transport, inhibiting the oxidation of LDL-c, and neutralizing the herogenic effects of oxidized LDL-c. There is a correlation between the level of very-low-density lipoprotein-c (vLDL-c) and HDL-c. A significant increase in LDL-c and vLDL-c levels may lead to a significant decrease in HDL-c levels. In addition, lower HDL-c levels can also occur because of reduced activity in lecithincholesterol acyltransferase (LCAT) (Al-Numair , 2010). A previous studies show that the administration of camel milk can help decrease the levels of cholesterol in diabetic patients (Agrawal et al., 2003, Mohamad et al., 2009, El-Sayed et al ., 2011 and Lusis, 2000). 


\section{Abdel-Mobdy, A. E, Amall. Abdel-Mohsin, Aly, H. E and Abdel-.Rahim, E. A.}

Dyslipidaemia has been implicated as the major risk factor of cardiovascular diseases. The World Health Organization (WHO) holds it responsible for more than four million deaths annually (Oguejiofor et al.,2012). Accumulation of triglycerides and other fats in the hepatocytes, if not treated, results in inflammatory conditions of the liver. It is characterized by varying degree of liver injury ranging from steatosis to steatohepatitis, fibrosis and necrosis (Day and James, 1998).

In one study Sboui et al., (2010), alloxan-induced diabetic dogs treated with camel milk (Group 1) showed a statistically significant decrease $(p<0.05)$ in the total cholesterol (TC) level from $6.17 \pm 0.15 \mathrm{mmol} / \mathrm{L}$ to $4.35 \pm 0.61 \mathrm{mmol} / \mathrm{L}$ after 5 weeks. In this period, diabetic dogs treated with cow milk (Group 2) showed an increase in the TC level from $5.99 \pm 0.58 \mathrm{mmol} / \mathrm{L}$ to $7.13 \pm 1.25$ $\mathrm{mmol} / \mathrm{L}$ (El-Said et al., 2010, Sboui et al., 2010, Khan et al., 2012, Al-Numair, 2010 and Ali et al., 2013). However, the diabetic dogs in Group 2 were treated with camel milk instead of cow milk for the next 5 weeks, and showed a $30 \%$ improvement in the TC level.

Furthermore, diabetic dogs from Group 1 showed an improvement in lipid profile even after 5 weeks of having stopped drinking camel milk (Sboui et al., 2010). Al-Numair, (2010) reported that the administration of camel milk is able to reduce hyperlipidemia that is associated with the risk of diabetes mellitus (DM). Also the study found that TC, triacylglycerols (TG), free fatty acid (FFA), phospholipids (PLs), LDL-C, and VLDL-C levels significantly decreased $(p<0.05)$ towards normal levels in plasma and tissues (e.g., liver, kidneys, and heart), whereas the plasma HDL-C significantly improved in diabetic rats after treatment with camel milk 
Egyptian J. of Nutrition Vol. XXXIV No. 2 (2019)

for 21 days. Another study conducted by El-Said et al., (2010) to evaluate the effect of camel milk on lipid profile in experimentally induced diabetic rabbits was not in agreement with the previous findings. To evaluate the protective role of camel milk against dyslipidemia, changes in the lipid profile levels were analyzed in streptozotocin (STZ) induced diabetic rats in the study of Khan et al., (2012).

Their results of this study indicated that the levels of TC, TG, and LDL-c were significantly higher $(p<0.05)$ in the control group of diabetic rats and these levels were significantly reduced in the group of rats fed camel milk. Other researchers studied the hypocholesterolemic effect of Gariss (i.e., fermented camel milk) on the levels of lipid profile of rats (Ali et al., 2013).

Therefore, the aim of the present studies was to evaluate in vivo the effect of camel milk as a potential therapy on controlling hyperlipidemia (obesity) and its complications such as high cholesterol levels, liver and kidneys disease, also decreased oxidative stress.

The present studies were undertaken to investigate the effect of camel milk on their biological and nutritional evaluation through an animal experiment as following studies:

1- Chemical composition of camel milk.

2- $\quad$ The biological treatments of camel milk by $1 \mathrm{ml}, 1.5 \mathrm{ml}$ and 2 $\mathrm{ml}$ as antioxidants and antitoxins agents on blood analysis, via., glucose, lipid profile, liver function, kidneys function and heart function as well as body weight gain. 


\section{Abdel-Mobdy, A. E, Amall. Abdel-Mohsin, Aly, H. E and Abdel-.Rahim, E. A.}

\section{Materials and Methods}

\section{Preparation of samples :}

Samples of the present study were purchased from hard farm of camel animals Kerdasa, Giza, Egypt. The samples were used fresh warm milk at arrived in the morning as treatment doses of orally ingestion using stomach tube which was equivalent to $1,1.5$ and $2 \mathrm{ml}$ milk / $100 \mathrm{~g}$ body weight / day after day in animal experiments.

\section{General chemical analysis:}

The determination the percentages of moisture, crude protein, total lipids and ash were done, nitrogen free extract (total carbohydrate) was calculated by difference, according to A.O.A.C. (2000).

\section{Biological effects of investigated plan:}

\section{Experimental animals :}

The Spraque-Dawley albino male, rats weighing $130-160 \mathrm{~g}$ were used for the present study. The animals were obtained from Agriculture Research Centre (A.R.C.), Giza, Egypt. The animals were raised in the animal house of Fac. Agric. Cairo Univ. Giza, Egypt. The rats were kept under normal laboratory conditions (temperature remain $25 \pm 2^{\circ} \mathrm{C}$ ) for $48 \mathrm{hr}$. before the initiation of experiment. During the experimental period ( 7 week), the animals were allowed free access of water and basal diet. Food consumption and body weight were monitored daily for each animal. 
Egyptian J. of Nutrition Vol. XXXIV No. 2 (2019)

\section{Animal diet:}

\section{a. Health diet}

The control diet is composed of as reported by Lane-Peter and Pearson (1971) 15\% casein, 10\% corn oil, 5\% cellulose, $4 \%$ salt mixture (Schneeman et al., 1989), 1\% vitamins mixture (Philip et al., 1993) and starch $65 \%$.

\section{b. Hyperlipidemic diet}

On the other hands, high fat diet was similar to the control diet but differ in fat content which was $20 \%$ sheep fat, $2 \%$ cholesterol, $0.25 \%$ bile salts and starch $42.75 \%$ to produce the hyperlipidemic / hypercholesteralemic status.

At the end of the feeding period blood samples were taken from the Supraorbitalvein to test for blood lipid profile levels. A high levels of plasma cholesterol and triglycerides were considered as an indication to hypercholesterolemia and hyperlipidemia. The hyperlipidemic rats of the second group were subdivided into 4 groups (5 rats/group):

\section{Experimental design:}

After a period of adaptation (48 h.), 25 adult rats weighing between 130 - $160 \mathrm{~g}$ were divided into five groups :

Group (1): (Healthy control group) (G1) : Rats were given normal diet (5 rats) as health control.

Group (2): (Hyperlipidemic control group) (G2) : Rats were fed on high fat/high cholesterol diet without any treatment.

Group 3: (Camel Milk. Dose $1 \mathrm{ml}$ ). (G3) : Rats were fed on high fat/high cholesterol diet next to dose of treatment $1 \mathrm{ml} / 100 \mathrm{~g}$ body weight / day after day from camel milk group . 


\section{Abdel-Mobdy, A. E, Amall. Abdel-Mohsin, Aly, H. E and Abdel-.Rahim, E. A.}

Group 4: (Camel Milk. Dose $1.5 \mathrm{ml}$ ). (G4) : Rats were fed on high fat/high cholesterol diet next to dose of treatment $1.5 \mathrm{ml} / 100 \mathrm{~g}$ body weight / day after day from camel milk group .

Group 5: (Camel Milk. Dose $2 \mathrm{ml}$ ). (G5) : Rats were fed on high fat/high cholesterol diet next to dose of treatment $2 \mathrm{ml} / 100 \mathrm{~g}$ body weight / day after day from camel milk group .

The treated that rats were given the doses of treatments orally ingestion by stomach tube adding to high fat with cholesterol diet for 7 weeks.After that, rats were fasted overnight and then the animals were killed by decapitation and blood samples were collected from each rat with EDTA and subjected to centrifugation tube at $3000 \mathrm{xg}$ to obtain the plasma which was kept in the deep freezer for the subsequent investigation.

\section{Blood biochemical analysis:}

Determination of plasma glucose:

Enzymatic determination of plasma glucose was carried out calorimetrically according to the method of Trinder(1969).

\section{Liver function:}

For liver function AST and ALT (transaminases) activities were determined calorimetrically according to the method of Reitman and Frankel (1957).

\section{Kidneys function:}

For kidneys function urea contents in plasma were determined calorimetrically according to the methods described by Caraway (1975) and the determination of plasma creatinine content was carried out calorimetrically 'according to the methods described by Faulkner and King (1976). 
Egyptian J. of Nutrition Vol. XXXIV No. 2 (2019)

Plasma lipid and lipoprotein profile:

For plasma lipid profile, the total lipids, total triglycerides and total cholesterol levels were determined calorimetrically according to the methods of Knight et al., (1972), Fossati and Prencipe (1982) and Allain et al., (1974) respectively. But for lipoprotein profile in plasma, HDL-cholesterol and LDL-cholesterol levels were determined according to Warmick et al., (1983) and Bergmenyer (1985) respectively, vLDL-cholesterol was calculated by using the equation which was described by Fiedewaid et al., (1972).

\section{Statistical analysis:}

All data pooled through this study were proceeded by General Linear Model procedures (GLM) of the statistical analysis system described in SAS User's Guide (SAS Institute, 2000)., The significance of the differences among treatment) groups were tested using Waller-Duncan k-ratio (Waller and Duncan, 1969). All statements of significance were based on probability of $P<0.05$

\section{Results and Discussion}

\section{Results}

Chemical composition of camel milk:

Camel milk considered from famous Dairy in Egypt. The chemical composition of camel milk are shown in Table (1). It could be observed that camel milk are contains protein, fat, elements metal and carbohydrates in a good amounts, the camel milk contain amount large of vitamin A, Potassium (K), Iron (Fe), Zinc (Zn) and Copper $(\mathrm{Cu})$. Recently, a special interest was given to milk vitamins and elements metal as good antioxidants, antilipidimic, anticholesterolemic agents and detoxification as antitoxins. For that 


\section{Abdel-Mobdy, A. E, Amall. Abdel-Mohsin, Aly, H. E and Abdel-.Rahim, E. A.}

the present studies analyzed the elements, vitamins, etc. compounds of camel milk. The chemical analysis of camel milk for their chemical compounds (table 1) showed the presence 19 compounds. These results are in agreement with Hamad et al., (2012) who found about similar data.

\section{Effects of different therapeutic doses of camel milk on body weight gain and feed efficiency of the experimental rats:}

The data presented in tables (2) showed that the hypercholesterolemic diets did not change the food intake but significantly increased the body weight gain and feed efficiency of male albino rats compared to normal control. The feeding on different therapeutic doses ofcamelmilk for hypercholesterolemic rats resulted insignificant changes at that of normal control and hypercholesterolemic groups for food intake, but body weight gain and feed efficiency showed significant improvements and decreases at the diseased group rats. The gain in body weight at the end of the experimental period ( 7 week) for the normal control was $230 \mathrm{~g}$, while for the diseased control rats was $259 \mathrm{~g}$. Feeding on camel milk by dose $2 \mathrm{ml}, 1.5 \mathrm{ml}$ and $1 \mathrm{ml}$, showed body weight gain of 241, 243 and 246 grespectively. This means that the treatment with dose 2 and 1.5 $\mathrm{ml}$ showed improved body weight gain which had a good effect against the hyperlipidemia.

These values were still more than that of normal health control. Concerning food intake, the values for normal control was $758 \pm 53 \mathrm{~g}$ but for the hypercholesterolemic group was $756 \pm 47$ while for other group, at was ranged between $758 \pm 51$ and $761 \pm 52 \mathrm{~g}$ which showed insignificant variation between each other. 
Egyptian J. of Nutrition Vol. XXXIV No. 2 (2019)

Effects of different therapeutic doses of camel milk on lipid profile of the experimental rats:

The studies are considered to be treatment investigations which were done on male albino rats.

Results of the evaluation of the five studied rat groups as hypocholesterolemic, hypolipidemic agents detoxification in albino rats were statistically analyzed Tables ( 3 and 4 ) which presented the lipid and lipoprotein profiles of the five groups at the end of the experimental period to the treatments of hyperlipidemia as a toxic agent ( 7 weeks).

The data pointed out a significant increase in total lipids, cholesterol and triglycerides when rats fed on the high fat/cholesterol diet, the values amounted 574, 365 and $249 \mathrm{mg} / \mathrm{dl}$ respectively relative to that of normal control which showed values of 268, 129 and $134 \mathrm{mg} / \mathrm{dl}$ respectively. The results show the effect of different doses ingestion of camel milk treatments on lipid profile of hyperlipidemic animals (table 3 ).

In case of hypolipidemic animals, the feeding on different dose of camel milk treatments exhibited different effects on the blood lipid profiles of the three treatments which significantly alleviated the harmful of hypolipidemia where the dose of camel milk 2 and $1.5 \mathrm{ml}$ treatments showed the most effective as hypolipidemic and hypocholesterolemic agents than that of dose of camel milk $1 \mathrm{ml}$ treatment. On the other hands, the dose of camel milk 2 and $1.5 \mathrm{ml}$ treatment possessed remarkable hypolipidemic and hypocholesterolemic activity but the levels of total lipids, cholesterol and triglycerides in blood were still slightly than that of the control. 


\section{Abdel-Mobdy, A. E, Amall. Abdel-Mohsin, Aly, H. E and Abdel-.Rahim, E. A.}

The results are in agreement of those data of blood lipoproteins content of the present study in table (4) except the HDLcholesterol (HDL-c).

The effects of different doses of camel milk treatments on hyperlipidemic animals was also different. Hyperlipidemia significantly decreased blood HDL-c, but increased LDL-c and vLDL-c contents. This drastic effect of hyperlipidimia was improved by the present treatments whereas, attenuationsand increases in HDL-c content of blood of hyperlipidemic animals observed after treatments by feeding on different dose of camel milk treatment. In contrast, LDL-C and vLDL-C contents in blood of hyperlipidemic rats were significantly alleviated by the present treatments which were reduced but the levels were still higher than that of control animals. From the present results the hypolipidemic and hypocholesterolemic effects of the different treatments can be arranged in the following increasing order: camel milk $(1 \mathrm{ml})<$ camel milk $(1.5 \mathrm{ml})<$ camel milk $(2 \mathrm{ml})$

\section{Effects of different therapeutic doses of camel milk on liver function and kidneys function of the experimental rats:}

The effects of the present antilipidemic agents on kidneys and liver functions ofobesity / hyperlipidemic rats were statistically analyzed and illustrated in table (5) .

The results showed that hyperlipidemia and hypercholesterolemia significantly stimulated and increasedAST and ALT activity. These observation indicated slight liver cell necrosis and the magnitude of increase correlated with the extent necrosis (Murray et al., 2006). The all different dose of camel milk treatments (as hypolipidemic and antitoxins agents) into diseased animals were 
Egyptian J. of Nutrition Vol. XXXIV No. 2 (2019)

characterized by an alleviation and normalization in the both transaminases activity of plasma.

These are conflicting report on the change in the blood changes. Alterations in liver function enzymes in plasma may be due to the harmful ofthe pathogenesis oflipidemia and cholesterolemia (Chatterjea and Shinde, 2002).

The treatment with the present antilipidemic agents (camel milk) was characterized by normalization in both transaminases activity content of plasma in diseased animals.

The effects of present treatments on kidneys functions of obesity hyperlipidemic animals was done by determination of blood urea and creatinine which were statistically analyzed. The data in table (6) showed that hyperlipidemia / hypercholesterolemia caused a significant increase at control in urea and creatinine contents of the diseased animal blood. The different dose of camel milk treatments as lipotropic factors for present diseased rats produced a significant improvements in the two parameters of kidneys functions.

The highest treatment effect on kidneys function was detected by the dose of 2 and $1.5 \mathrm{ml}$ camel milk. The feeding of camel milk (1 $\mathrm{ml}$ ) produced lower improved effects in the same respect. These effects were similar to those of the liver function which are unlikely to be due damage in liver and kidneys tissue (Murray et al., 2012) also have been thought to be significant in the pathogenesis of lipidemia.

Effects of different therapeutic doses of camel milk on blood glucose and heart function by LDH activity of the experimental rats: 


\section{Abdel-Mobdy, A. E, Amall. Abdel-Mohsin, Aly, H. E and Abdel-.Rahim, E. A.}

The results presented in table (7) indicated that the hyperlipidemia effects on blood glucose and heart function (LDH activity) in blood which were statistically analyzed. These results showed that hyperlipidemia significantly increased the values of blood glucose level relative to healthy control animals. Also, the present data showed that the LDH activity was significantly increased by lipidemia or cholesterolemia. The data observed that there occurred a significant increase in plasma heart function in the diseased animals. Also, these results pointed out that the feeding on camel milk and as antioxidant diet caused an improvement in the heart function values. Also, the present antioxidant diets alleviated the harmful effects of hyperlipidemia on heart function. These values were still slightly far from that of normal healthy control animals.

\section{Discussion}

Dairy plays an important role in human nutrition, especially camel's milk. Chemotherapy has been shown to be a source of proteins, calories, certain minerals, vitamins and antioxidants (such as vitamin $A$ and vitamin $E$, iron, copper, zinc,and potassium) .Current results can be reported using camel milk as a food remedy against lipidemia /cholesterolemia which had significantly improved effects on lipid profile, LDH heart enzyme activity, kidneys function and liver function of blood. Also, either improved doses of camel milk treatments have alleviated the harmful effects of hyperlipidemia and hyperlipidemia. Major contributors to the accumulation of cholesterol in the cell arteries during the development of atherosclerosis include several factors such as the high level of plasma cholesterol (Joanne et al., 2005), inhibit paroxinaseofblood (Lee et al., 2008), increase serum cholesterol level (Aviram et al., 2000) with regard to the most 
Egyptian J. of Nutrition Vol. XXXIV No. 2 (2019)

effective factor increase of oxidative stress (Van Lieshout et al., 2003). This has been presented in a number of studies to look for feeding on food rich in protein and antioxidant that can be preventive to atherosclerosis among exposed individuals. The improvement in lipid profile of blood could have been referred to a multi factors near the role of amino acids of protein, unsaturated fatty acids and antioxidants may play a good part in this action.

The beneficial treatment of camel milk on cholesterol-bearing rats has shown that protein and antioxidant have the potential to lower total cholesterol levels and LDL-c in plasma. Absorption of bile salts by soluble dietary fibres (SDF) results changes in cholesterol metabolism, loss of cholesterol, lack of bile salts in the intestines to form micelle, which results in absorption of fat and cholesterol. Increased fecal bolts dilutes bile acid in the lower intestine, producing short-chain fatty acids. In particular, propionate has been suggested to inhibit the synthesis of cholesterol in the liver (Tharanathan and Mahadevamma, 2003).

Also, amino acids of the present dietary food (camel milk) used as precursors of lipoprotein, including HDL-c which has $50 \%$ of its structure protein (Elliott and Elliott, 2001), that via protein biosynthesis and also the three hypophseal peptides that simulate fatty acids (catabolism). In addition, these amino acids are considered as lipotropic factors used in the protein biosynthesis of $\beta$ oxidation enzymes, glucose oxidase, antioxidant enzymes (SOD and catalase) and other protein factors.

These are suggesting that dietary protein outputs its hypolipidemic effects by stimulating $\beta$-oxidation fatty acids at the expense of fatty acids esterification (Wang and Jones, 2004) which is 


\section{Abdel-Mobdy, A. E, Amall. Abdel-Mohsin, Aly, H. E and Abdel-.Rahim, E. A.}

believed to possess a strong antioxidant property, including its ability to search for or prevent many types of corn oxygen Reactive and inhibits lipid peroxidation (Kaplan et al., 2001 and Lee et al., 2006). It showed that camel's milk contained an antioxidant strength appreciated.

This means that the effects of camel milk associated with the lack of blood lipids which are mainly related to the antioxidant elements, and also related to protein for camel's milk. The chemical analysis pattern seems to agree with $\mathbf{L i}$ et al., (2006).

It is clear that these chemical compounds are detected in camel's milk responsible for the antioxidant effect and cholesterol reduction. The effect of hypoglycaemia may be either due to the effect of inhibitory on lipid absorption or increase in receptors LDLcholesterol.

The influences the work of antioxidants of camel milk suggestedthat it was due to the ability of antioxidants to transfer electron anion free radicals, metal catalyst dogs, enzymes active antioxidants as stated in current studies and prevent oxidases (Spencer et al., 2001).

Therefore, the peripheral mechanism of action of current treatments and especially the high doses of camel's milk may be the main activity responsible for the subsequent activity of inflammation of protein and antioxidants, although other target organs (liver and kidneys) can't be eliminated. The most obvious effect of the 2and 1.5 $\mathrm{ml}$ milk compared to others alone is the synergistic effect of the three food systems, resulting in good dilution and improvement in severe 
Egyptian J. of Nutrition Vol. XXXIV No. 2 (2019)

lipid effects such as blood and antihypertensive agents. This may be due to the fact that the milk is composed of an optimal combination agent such as protein, antioxidant agents, vitamin A, C, E and compounds B.This also was addition to iron, copper, zinc and potassium. Current results are in harmony with each other. Thus stimulating the transaminases activity content in the blood of rats studied, which has been used largely as an indicator of liver function.

Also, urea and creatinine in blood, confirmed each other as well as previous results. Therefore, further studies are needed to assess the biochemical effects and mechanism of the factors studied for lipids and antioxidants as agents antilipidemic and anticholesterolemic Which may be used in edible foods to recommend their use as hypodermic food additives. 
Abdel-Mobdy, A. E, Amall. Abdel-Mohsin, Aly, H. E and Abdel-.Rahim, E. A.

Table (1) : Nutritious Values in Camel Milk

\begin{tabular}{c|c|c|c}
\hline No. & Components & Camel & \\
\hline 1 & Water & 86.97 & $\%$ \\
\hline 2 & Ash & 0.85 & $\%$ \\
\hline 3 & Protein & 3.26 & $\%$ \\
\hline 4 & Lactose & 4.97 & $\%$ \\
\hline 5 & Fat & 3.95 & $\%$ \\
\hline 6 & Total solids & 12.8 & $\%$ \\
\hline 7 & Vitamin A & 0.3 & $\mathrm{mg} / 100 \mathrm{ml}$ \\
\hline 8 & Vitamin B1 (Thiamin) & 0.04 & $\mathrm{mg} / 100 \mathrm{ml}$ \\
\hline 9 & Vitamin B2 (Riboflavin) & 0.18 & $\mathrm{mg} / 100 \mathrm{ml}$ \\
\hline 10 & Vitamin C & 1.1 & $\mathrm{mg} / 100 \mathrm{ml}$ \\
\hline 11 & Vitamin E & 0.12 & $\mathrm{mg} / 100 \mathrm{ml}$ \\
\hline 13 & Sodium (Na) & 43 & $\mathrm{mg} / 100 \mathrm{ml}$ \\
\hline 14 & Potassium $(\mathrm{K})$ & 153 & $\mathrm{mg} / 100 \mathrm{ml}$ \\
\hline 15 & Calcium (Ca) & 110 & $\mathrm{mg} / 100 \mathrm{ml}$ \\
\hline 16 & Phosphors $(\mathrm{p})$ & 84.99 & $\mathrm{mg} / 100 \mathrm{ml}$ \\
\hline 17 & Magnesium $(\mathrm{Mg})$ & 12.99 & $\mathrm{mg} / 100 \mathrm{ml}$ \\
\hline 18 & Iron (Fe) & 0.44 & $\mathrm{mg} / 100 \mathrm{ml}$ \\
\hline 19 & Zinc (Zn) & 0.96 & $\mathrm{mg} / 100 \mathrm{ml}$ \\
\hline 20 & Copper (Cu) & 0.1 & $\mathrm{mg} / 100 \mathrm{ml}$ \\
\hline & Chloride $(\mathrm{Cl})$ & 0.125 & $\mathrm{mg} / 100 \mathrm{ml}$ \\
\hline & & &
\end{tabular}


Egyptian J. of Nutrition Vol. XXXIV No. 2 (2019)

Table(2): Body weight gain ,food intake and food efficiency of the experimental animals

\begin{tabular}{|c|c|c|c|c|c|c|}
\hline Treatment & $\begin{array}{l}\text { Initial } \\
\text { B.W } \\
\text { (g) }\end{array}$ & $\begin{array}{l}\text { Final } \\
\text { B.W } \\
(\mathrm{g})\end{array}$ & $\begin{array}{l}\text { B.W } \\
\text { gain } \\
\text { (g) }\end{array}$ & $\begin{array}{l}\text { feed } \\
\text { intake } \\
\text { (g) }\end{array}$ & $\begin{array}{c}\text { feed } \\
\text { efficiency } \\
\% 100\end{array}$ & $\begin{array}{l}\% \text { at } \\
\text { control }\end{array}$ \\
\hline $\begin{array}{l}\text { N.control health } \\
\text { group (G1) }\end{array}$ & $\begin{array}{c}160 \pm \\
8^{a}\end{array}$ & $\begin{array}{c}230 \pm \\
16^{c}\end{array}$ & $\begin{array}{l}70 \pm \\
3.8^{c}\end{array}$ & $\begin{array}{c}758 \pm \\
53^{a}\end{array}$ & $9.23^{d}$ & 100 \\
\hline $\begin{array}{l}\text { Intoxicated Hyper } \\
\text { lipidimic control } \\
\text { group (G2) }\end{array}$ & $\begin{array}{c}164 \pm \\
6^{a}\end{array}$ & $\begin{array}{c}259 \pm \\
16^{a}\end{array}$ & $\begin{array}{c}95 \pm \\
10.2^{\mathrm{a}}\end{array}$ & $\begin{array}{c}756 \pm \\
47^{a}\end{array}$ & $12.57^{\mathrm{a}}$ & 136 \\
\hline $\begin{array}{l}\text { Camel } 1 \mathrm{ml} \text { group } \\
\text { (G3) }\end{array}$ & $\begin{array}{c}162 \pm \\
7^{a}\end{array}$ & $\begin{array}{c}246 \pm \\
12^{b}\end{array}$ & $\begin{array}{l}84 \pm \\
4.8^{b}\end{array}$ & $\begin{array}{c}758 \pm \\
50^{a}\end{array}$ & $11.08^{b}$ & 120 \\
\hline $\begin{array}{l}\text { Camel } 1.5 \mathrm{ml} \\
\text { group (G4) }\end{array}$ & $\begin{array}{c}164 \pm \\
8^{a}\end{array}$ & $\begin{array}{c}243 \pm \\
11^{b}\end{array}$ & $\begin{array}{l}79 \pm \\
4.0^{b}\end{array}$ & $\begin{array}{c}761 \pm \\
52^{a}\end{array}$ & $10.38^{c}$ & 112 \\
\hline $\begin{array}{l}\text { Camel } 2 \text { ml group } \\
\text { (G5) }\end{array}$ & $\begin{array}{c}163 \pm \\
8^{a}\end{array}$ & $\begin{array}{c}241 \pm \\
15^{b}\end{array}$ & $\begin{array}{l}78 \pm \\
4.2^{b}\end{array}$ & $\begin{array}{c}758 \pm \\
51^{a}\end{array}$ & $10.29^{c}$ & 111 \\
\hline
\end{tabular}

Table (3): Lipid fraction of the experimental animals

\begin{tabular}{|c|c|c|c|c|c|c|}
\hline \multirow{2}{*}{ Treatment } & \multicolumn{2}{|c|}{ Tolal Lipid } & \multicolumn{2}{|c|}{$\begin{array}{c}\text { Total } \\
\text { Cholesterol }\end{array}$} & \multicolumn{2}{|c|}{ Tri Gylciraide } \\
\hline & $\mathrm{mg} / \mathrm{dL}$ & $\begin{array}{c}\% \text { at } \\
\text { control }\end{array}$ & $\mathrm{mg} / \mathrm{dL}$ & $\begin{array}{c}\text { \%at } \\
\text { control }\end{array}$ & $\mathrm{mg} / \mathrm{dL}$ & $\begin{array}{c}\% \text { at } \\
\text { control }\end{array}$ \\
\hline $\begin{array}{l}\text { N.control health group } \\
\qquad(\mathrm{G} 1)\end{array}$ & $\begin{array}{c}268 \pm \\
14^{d}\end{array}$ & 100 & $\begin{array}{c}129 \pm \\
11^{d}\end{array}$ & 100 & $\begin{array}{c}134 \pm \\
18^{c}\end{array}$ & 100 \\
\hline $\begin{array}{c}\text { Intoxicated Hyper } \\
\text { lipidimic control group } \\
\text { (G2) }\end{array}$ & $\begin{array}{c}574 \pm \\
59^{a}\end{array}$ & 214 & $\begin{array}{c}365 \pm \\
39^{a}\end{array}$ & 283 & $\begin{array}{c}249 \pm \\
23^{a}\end{array}$ & 186 \\
\hline Camel $1 \mathrm{ml}$ group (G3) & $\begin{array}{c}461 \pm \\
33^{b}\end{array}$ & 172 & $\begin{array}{c}279 \pm \\
13^{b}\end{array}$ & 216 & $\begin{array}{c}201 \pm \\
11^{\mathrm{b}}\end{array}$ & 150 \\
\hline $\begin{array}{l}\text { Camel } 1.5 \mathrm{ml} \text { group } \\
\text { (G4) }\end{array}$ & $\begin{array}{c}453 \pm \\
22^{\mathrm{bc}}\end{array}$ & 169 & $\begin{array}{c}257 \pm \\
19^{b}\end{array}$ & 199 & $\begin{array}{c}198 \pm \\
14^{\mathrm{b}}\end{array}$ & 148 \\
\hline Camel 2 ml group (G5) & $\begin{array}{c}424 \pm \\
25^{c}\end{array}$ & 158 & $\begin{array}{c}220 \pm \\
15^{c}\end{array}$ & 171 & $\begin{array}{c}187 \pm \\
14^{\mathrm{b}}\end{array}$ & 140 \\
\hline
\end{tabular}

- Each value represents the mean of 5 rats (Mean \pm SE) after7 weeks experimental period.

- Means in the same column followed by the same letter are not significantly different at $(\mathrm{P}<0.05)$. 
Abdel-Mobdy, A. E, Amall. Abdel-Mohsin, Aly, H. E and Abdel-.Rahim, E. A.

Table (4): Lipoprotein profile of the experimental animals

\begin{tabular}{|c|c|c|c|c|c|c|}
\hline \multirow[b]{2}{*}{ Treatment } & \multicolumn{2}{|c|}{$H D L-c$} & \multicolumn{2}{|c|}{$L D L-c$} & \multicolumn{2}{|c|}{$v L D L-c$} \\
\hline & $\mathrm{mg} / \mathrm{dL}$ & $\begin{array}{c}\% \text { at } \\
\text { control }\end{array}$ & $\mathrm{mg} / \mathrm{dL}$ & $\begin{array}{c}\% \text { at } \\
\text { control }\end{array}$ & $\mathrm{mg} / \mathrm{dL}$ & $\begin{array}{c}\% \text { at } \\
\text { control }\end{array}$ \\
\hline $\begin{array}{ll}\text { N.control } & \text { health } \\
\text { group }(\mathrm{G} 1) & \end{array}$ & $\begin{aligned} & 38 \\
\pm & 2.1^{\mathrm{a}}\end{aligned}$ & 100 & $\begin{array}{r}72 \\
\pm 3 d\end{array}$ & 100 & 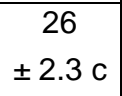 & 100 \\
\hline $\begin{array}{lr}\text { Intoxicated } & \text { Hyper } \\
\text { lipidimic } & \text { control } \\
\text { group (G2) } & \end{array}$ & $\begin{aligned} & 18 \\
\pm & 1.3 \mathrm{c}\end{aligned}$ & 48 & $\begin{array}{l}282 \\
\pm 23 \mathrm{a}\end{array}$ & 392 & $\begin{array}{c}53 \\
\pm 2.4 \mathrm{a}\end{array}$ & 205 \\
\hline $\begin{array}{l}\text { Camel } 1 \mathrm{ml} \text { group } \\
\text { (G3) }\end{array}$ & $\begin{aligned} & 25 \\
\pm & 1.8 \mathrm{~b}\end{aligned}$ & 66 & $\begin{array}{r}203 \\
\pm 8 b\end{array}$ & 282 & $\begin{array}{c}46 \\
\pm 2.8 \mathrm{~b}\end{array}$ & 177 \\
\hline $\begin{array}{l}\text { Camel } 1.5 \mathrm{ml} \text { group } \\
\text { (G4) }\end{array}$ & $\begin{aligned} & 25 \\
\pm & 1.4 \mathrm{~b}\end{aligned}$ & 67 & $\begin{array}{r}185 \\
\pm 9 \mathrm{~b}\end{array}$ & 258 & 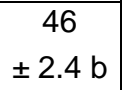 & 175 \\
\hline $\begin{array}{l}\text { Camel } 2 \mathrm{ml} \text { group } \\
\text { (G5) }\end{array}$ & $\begin{aligned} & 30 \\
\pm & 1.7 \mathrm{~b}\end{aligned}$ & 78 & $\begin{array}{r}152 \\
\pm 8 \mathrm{c}\end{array}$ & 211 & $\begin{array}{r}42 \\
\pm 2.2 \mathrm{~b}\end{array}$ & 161 \\
\hline
\end{tabular}


Egyptian J. of Nutrition Vol. XXXIV No. 2 (2019)

Table (5): Liver function of the experimental animals

\begin{tabular}{c|c|c|c|c|c|c}
\hline \multirow{2}{*}{ Treatment } & \multicolumn{2}{|c|}{ A S T } & \multicolumn{2}{c|}{ AL T } & \multicolumn{2}{c}{ Ratio A S T / ALT } \\
\cline { 2 - 7 } & $\mathrm{U} / \mathrm{L}$ & $\begin{array}{c}\% \text { at } \\
\text { control }\end{array}$ & $\mathrm{U} / \mathrm{L}$ & $\begin{array}{c}\text { \% at } \\
\text { control }\end{array}$ & $\begin{array}{c}\% \text { at } \\
\text { control }\end{array}$ \\
\hline $\begin{array}{c}\text { N.control health } \\
\text { group (G1) }\end{array}$ & $\begin{array}{c}117 \pm \\
9^{\mathrm{c}}\end{array}$ & 100 & $\begin{array}{c}60 \pm \\
4^{\mathrm{c}}\end{array}$ & 100 & $\begin{array}{c}1.95 \pm \\
0.12^{\mathrm{c}}\end{array}$ & 100 \\
\hline $\begin{array}{c}\text { Intoxicated Hyper } \\
\text { lipidimic control } \\
\text { group (G2) }\end{array}$ & $\begin{array}{c}229 \pm \\
16^{\mathrm{a}}\end{array}$ & 196 & $\begin{array}{c}90 \pm \\
5^{\mathrm{a}}\end{array}$ & 150 & $\begin{array}{c}2.55 \pm \\
0.21^{\mathrm{a}}\end{array}$ & 131 \\
\hline $\begin{array}{c}\text { Camel 1 ml group } \\
\text { (G3) }\end{array}$ & $\begin{array}{c}170 \pm \\
12^{\mathrm{b}}\end{array}$ & 145 & $\begin{array}{c}72 \pm \\
6^{\mathrm{b}}\end{array}$ & 120 & $\begin{array}{c}2.36 \pm \\
0.13^{\mathrm{b}}\end{array}$ & 121 \\
\hline $\begin{array}{c}\text { Camel 1.5 ml group } \\
\text { (G4) }\end{array}$ & $\begin{array}{c}163 \pm \\
13^{\mathrm{b}}\end{array}$ & 139 & $\begin{array}{c}70 \pm \\
3^{\mathrm{bc}}\end{array}$ & 116 & $\begin{array}{c}2.34 \pm \\
0.17^{\mathrm{b}}\end{array}$ & 120 \\
\hline $\begin{array}{c}\text { Camel 2 ml group } \\
\text { (G5) }\end{array}$ & $\begin{array}{c}159 \pm \\
12^{\mathrm{b}}\end{array}$ & 136 & $\begin{array}{c}68 \pm \\
5^{\mathrm{bc}}\end{array}$ & 113 & $\begin{array}{c}2.34 \pm \\
0.18^{\mathrm{b}}\end{array}$ & 120 \\
\hline
\end{tabular}

- Each value represents the mean of 5 rats (Mean \pm SE) after7 weeks experimental period.

- Means in the same column followed by the same letter are not significantly different at $(\mathrm{P}<0.05)$. 
Abdel-Mobdy, A. E, Amall. Abdel-Mohsin, Aly, H. E and Abdel-.Rahim, E. A.

Table (6): Kidneys function of the experimental animals

\begin{tabular}{l|c|c|c|c}
\hline \multirow{2}{*}{ Treatment } & \multicolumn{2}{|c|}{ Urea } & \multicolumn{2}{c}{ Creatinine } \\
\cline { 2 - 5 } & $\mathrm{mg} / \mathrm{dL}$ & $\%$ at control & $\mathrm{mg} / \mathrm{dL}$ & $\%$ at control \\
\hline N.control health group (G1) & $58 \pm 7^{\mathrm{b}}$ & 100 & $\begin{array}{l}0.9 \pm \\
0.04^{\mathrm{d}}\end{array}$ & 100 \\
\hline Intoxicated Hyper lipidimic & $66 \pm 4^{\mathrm{a}}$ & 113 & $\begin{array}{c}1.6 \pm \\
0.02^{\mathrm{a}}\end{array}$ & 173 \\
\hline control group (G2) & $63 \pm 6^{\mathrm{ab}}$ & 109 & $\begin{array}{c}1.3 \pm \\
0.02^{\mathrm{b}}\end{array}$ & 144 \\
\hline Camel 1 ml group (G3) & $62 \pm 3^{\mathrm{ab}}$ & 107 & $\begin{array}{c}1.2 \pm \\
0.02^{\mathrm{b}}\end{array}$ & 136 \\
\hline Camel 1.5 ml group (G4) & $61 \pm 4^{\mathrm{ab}}$ & 105 & $\begin{array}{c}1.1 \pm \\
0.06^{\mathrm{c}}\end{array}$ & 122 \\
\hline Camel 2 ml group (G5) & & & & \\
\hline
\end{tabular}


Egyptian J. of Nutrition Vol. XXXIV No. 2 (2019)

Table (7)Blood glucose and L D H activity of the experimental animals

\begin{tabular}{l|c|c|c|c}
\hline \multirow{2}{*}{ Treatment } & \multicolumn{2}{|c|}{ Glucose } & \multicolumn{2}{c}{ L D H } \\
\cline { 2 - 5 } & $\mathrm{mg} / \mathrm{dL}$ & $\begin{array}{c}\% \text { at } \\
\text { control }\end{array}$ & $\mathrm{U} / \mathrm{L}$ & $\%$ at control \\
\hline N.control health group (G1) & $70 \pm 3^{\mathrm{c}}$ & 100 & $\begin{array}{c}1787 \pm \\
104^{\mathrm{b}}\end{array}$ & 100 \\
\hline $\begin{array}{l}\text { Intoxicated Hyper lipidimic control } \\
\text { group (G2) }\end{array}$ & $\begin{array}{c}126 \pm 6 \\
\mathrm{a}\end{array}$ & 180 & $\begin{array}{c}2698 \pm \\
114^{\mathrm{a}}\end{array}$ & 151 \\
\hline Buffalo 1 ml group (G3) & $95 \pm 3^{\mathrm{b}}$ & 136 & $\begin{array}{c}2448 \pm \\
141^{\mathrm{b}}\end{array}$ & 137 \\
\hline Buffalo 1.5 ml group (G4) & $92 \pm 4^{\mathrm{b}}$ & 131 & $\begin{array}{c}2412 \pm \\
176^{\mathrm{b}}\end{array}$ & 135 \\
\hline Buffalo 2 ml group (G5) & $87 \pm 7^{\mathrm{b}}$ & 125 & $\begin{array}{c}2363 \pm \\
140^{\mathrm{b}}\end{array}$ & 132 \\
\hline
\end{tabular}

- Each value represents the mean of 5 rats (Mean \pm SE) after7 weeks experimental period.

- Means in the same column followed by the same letter are not significantly different at $(\mathrm{P}<0.05)$. 


\section{Abdel-Mobdy, A. E, Amall. Abdel-Mohsin, Aly, H. E and Abdel-.Rahim, E. A.}

\section{References}

A.O.A.C. (2000).

Official Methods of Analysis of Association of Official Analytical Chemists, $17^{\text {th }}$ ed. Washington D.C., USA.

Agrawal R.P., Swami S.C., Beniwal R., Kochar D.K., Sahani M.S., Tuteja F.C., Ghouri S.K. (2003).

Effect of camel milk on glycemic control, lipid profile and diabetes quality of life in type 1 diabetes: a randomised prospective controlled cross over study. Indian J. Animal Sci;73:1105-1110.

Ali A.A., Alyan A.A. andBahobail A.S. (2013).

Effect of fermented camel milk and cow milk containing (bifidobacteria) enriched diet in rats fed on cholesterol level. Agric. Sci. Res. J.;3:342-346.

Allain, C.C.; Poon, L.S.; Chan, C.S.; Richamand, W. and Fu, P.C. (1974).

Enzymatic determination of total serum cholesterol. Clin. Chem., 20 (4): 470.

Al-Numair K.S. (2010).

Type II diabetic rats and the hypolipidemic effect of camel milk. J. Food Agric. Environ;8:77-81. 
Egyptian J. of Nutrition Vol. XXXIV No. 2 (2019)

Aviram, M.; Dorenfeld, L.; Rosenblat, M.; Volkova, N.; Kaplan, M. and Hayek, T. (2000).

Pomegranate juice consumption reduces oxidative stress, low density lipoprotein modifications and platelet aggregation: studies in the atheroscleroticapolipoprotein $E$ deficient mice and in humans. Am. J. Clin. Nutr., 71: 1062-1076.

Bergmenyer, H.U. (1985).

Methods of Enzymatic Analysis, vol. VIII (third ed.), 154-160.

Caraway, W.T. (1975).

Standard methods of clinical chemistry. Academic press, New York and London, 4: 239.

Chatterjea, M.N. and Shinde, R. (2002).

Text Book of Medical Biochemistry. Jaypee Brothers Medical Publishers, New Delhi.

Day C.P. and James O.F. (1998).

Steatohepatitis: a tale of two "hits" Gastroenterology.;114(4): 842-845.

Elliott, W.H. and Elliott, D.C. (2001).

Biochemistry and Molecular Biology $2^{\text {nd }}$ (ed.), Oxford University Press, Oxford.

El-Said E.E., El-Sayed G.R. andTantawy E. (2010).

Effect of camel milk on oxidative stresses in experimentally induced diabetic rabbits. Vet. Res. Forum;1:30-43. 


\section{Abdel-Mobdy, A. E, Amall. Abdel-Mohsin, Aly, H. E and Abdel-.Rahim, E. A.}

El-Sayed M.K., Al-Shoeibi Z.Y., Abd El-Ghany A.A. andAtef Z.A. (2011).

Effects of camel's milk as a vehicle for insulin on glycaemic control and lipid profile in type 1 diabetics. Am. J.Biochem. Biotechnol;7:179-189.

Faulkner, N.R.. and King, J.W. (1976).

Fundamental of clinical chemistry, $2^{\text {nd }}$ ed., Tietz (ed.), Sannders Philadelphia, 994-998.

Fiedewald, W.T.; Levy, R.I. and Fredrickson, D.S. (1972).

Estimation of concentration of low density lipoprotein cholesterol in plasma without use of the preparative ultracentrifuge. Clin. Chem., 18: 499-502.

Fontbonne A., Eschwege E., Cambien F., Richard J.L., Ducimetiere P., Thibult N., Warnet J.M., Claude J.R. andRosselin G.E. (1989).

Hypertriglyceridaemia as a risk factor of coronary heart disease mortality in subjects with impaired glucose tolerance or diabetes. Results from the 11-year follow-up of the Paris Prospective Study. Diabetologia;32:300-304.

Fossati, P. and Prencipe, L. (1982).

The determination of triglyceride using enzymatic methods. Clin. Chem., 28: 2077. 
Egyptian J. of Nutrition Vol. XXXIV No. 2 (2019)

Grundy S.M., Benjamin I.J., Burke G.L., Chait A., Eckel R.H., Howard B.V., Mitch W., Smith Jr S.C. and Sowers J.R. (1999).

Diabetes and cardiovascular disease: a statement for healthcare professionals from the American Heart Association. Circulation;100:1134-1146.

Gupta,A.(2011).

Hyperlipidemia. Department of Pharmacology, I.S.F college of Pharmacy,Moga-14200, Punjab. Int. J.Biopharmace.Toxicol. Res.. 1:81-89.

Hamad, E. M.; Abbel-Rahim, E.A. and Romeih, E.A.(2012)

Beneficial effect of camel milk on liver and kidneys function of diabetic Sprague-Dawleyrats. Int. J. Dairy Sci. 6 (3) : 190-197.

Joanne M.; Murabito, M.D.; Michael J.; Pencina, P.; Byung, H.; Nam, P.; Ralph, B. D'Agostino, Sr.; Thomas J.; Wang, M.D.; Donald Lloyd-Jones, M.D.; Peter, W.F.; Wilson, M.D.; Christopher, J. and O'Donnell, M.D. (2005).

Sibling Cardiovascular Disease as a Risk Factor for Cardiovascular Disease in Middle-aged Adults. J. Am. Med.Asso., 294: 3117-3123.

Kaplan, M.; Hayek, T.; Raz, A.; Coleman, R.; Dornfeld, L.; Vaya, J. and Aviram, M. (2001).

Pomegranate juice supplementation to atherosclerotic mice reduces macrophage lipid peroxidation, cellular cholesterol accumulation and development of atherosclerosis. J. Nutr., 131(8): 2082 - 2089. 


\section{Abdel-Mobdy, A. E, Amall. Abdel-Mohsin, Aly, H. E and Abdel-.Rahim, E. A.}

Khan A.A, AlzohairyM.A.andMohieldein A.H. (2012).

Antidiabetic effects of camel milk in streptozotocin-induced diabetic rats. Am. J.Biochem. Mol. Biol;3:151-158.

Knight, J.A.; Anderson, S.J. and Rawle, J.M. (1972).

Chemical basis of the sulfo-phosphovanillin reaction for estimating serum total lipids. Clin. Chem., 18 (3): 723.

Kopparapu , N. (2011).

MIRACLE NUTRIENT/ International Journal of Pharmacy and Technology.3,(2):1140-1164.

Lane-Peter, W. and Pearson, A.E. (1971).

Dietary require In The laboratory animal principles and practice". Academic press. London and New York.

Lee, M. S.; Pairk, J. Y.; Freake, H.; Kwun, I. S. and Kim, Y. (2008). Green tea catechin enhances cholesterol-7-alpha-hydroxylase gene expression in Hep.G2. Cells. Sr. J. Nutr., 99(6): I 1821185.

Li, Y.; Yang, J.; Wei, J.; Xu, J.; and Cheng, S. (2006).

Evaluation of antioxidant properties of pomegranate peel extract in comparison with pomegranate pulp extract. Food Chem., 96(2): 254-260.

Lusis JA. (2000).

Atheroscelerosis. Nature;407:233-241. 
Egyptian J. of Nutrition Vol. XXXIV No. 2 (2019)

Mohamad R.H., Zekry Z.K., Al-Mehdar H.A., Salama O., ElShaieb S.E., El-Basmy A.A., Al-Said M.G. andSharawy S.M. (2009).

Camel milk as an adjuvant therapy for the treatment of type 1 diabetes: verification of a traditional ethnomedical practice. J. Med. Food;12:461e5.

Motta M., Giugno I., Bosco S., Pistone G., Ruello P., Maugeri D. andMalaguarnera M. (2001).

Serum lipoprotein(a) changes in acute myocardial infarction. Panminerva Med;43:77-80.

Murray, R.K.; Granner, D.K. and Rodwell, V.W. (2006).

Harper'slllustrated Biochemistry, 27 $7^{\text {th }}$ ed. McGraw-Hil Education Casia.

Murray, R.K.; Bender, D.A., Bothan, R. M.; Kennel, P. J. Rodwell, V.W., and Weil P. A. (2012).

Harper'slllustrated Biochemistry, 29th ed. Large Medical Book.

Oguejiofor O.O., Onwukwe C.H. andOdenigbo C.U. (2012).

Dyslipidemia in Nigeria, Prevalence and Pattern, Ann. African Med.; 11(4):197-202.

Olorunnisola,O.; Bradley,G. and Afolayan,A.(2012).

Protective Effect of $\mathrm{T}$. violaceaRhizome Extract Against Hypercholesterolemia-induced oxidative stress in wistar Rats. Molecules 17:6033-6045. 


\section{Abdel-Mobdy, A. E, Amall. Abdel-Mohsin, Aly, H. E and Abdel-.Rahim, E. A.}

Philip G.R.; Forrest H.N. and George, C.F. (1993).

AIN-93 purified diets for laboratory rodents: final report of the American Institute of Nutrition Ad Hoc Writing committee on the reformulation of the AIN-76A rodent diet. J. Nutr., 123: 1935-1951.

Reitman, S. and Frankel, S. (1957).

A colorimetric method for the determination of serum glutamic oxaloacetic and glutamic pyruvic transaminases. Anal. J. Clin. Path., 28 (56): 56.

SAS institute (2000).

SAS/STAT User's Guide. SAS Institute Inc., Cary, NC.

Sboui A., Djegham M., Khorchani T., Hammadi M., Barhoumi K. andBelhadj O. (2010).

Effect of camel milk on blood glucose, cholesterol and total proteins variations in alloxan-induced diabetic dogs. Int. J.Diab. Metabol;18:5-11.

Schneeman, B.O.; Rice, R. and Richter, B.D. (1989).

Reduction of plasma and hepatic triacylglycerides with whole milk containing diets in rats. J. Nutr., 119: 965-970.

Spencer, J.P.; Schroeter, H.; Crossthwaithe, A.J.; Kuhnle, G.; Williams, R.J. and Rice-Evans, C. (2001).

Contrasting influences of glucuronidation and O-methylation of epicatechin on hydrogen peroxide-induced cell death in neurons and fibroblasts. Free Radic. Biol. Med., 31(9):11391146. 
Egyptian J. of Nutrition Vol. XXXIV No. 2 (2019)

Tharanathan R.N. and Mahadevamma, S. (2003).

Grain legumes- a boon to human nutrition. Trends Food Sci. Technol., 14: 507-518.

Trinder, P. (1969).

Determination of blood glucose using an oxidation peroxidase system with a non carcinogenicchromogene. Ann. Clin. Biochem., 6: 24.

Van Lieshout, M.; West, C. E. and van Breemen, R.B. (2003).

Isotopic tracer techniques for studying the bioavailability and bioefficacy of dietary carotenoids, particularly \{beta\}-carotene, in humans: a review. Am. J. Clin.Nutr., 77(1): 12 - 28.

Waller, R. A. and Duncan, D. B. (1969).

A Bayes rule for symmetric multiple comparisons problems. J. of the Am. Stat.Asso., 64: 1484-1503.

Wang, Y. and Jones, P. (2004).

Dietary conjugated linoleic acid and body composition. Am. J. of Clin.Nutr., 79 (6): 1153-1158.

Warnick,G.R.; Benderson, J. and Albers, J.J. (1983).

Selected Methods. Clin .Chem., 10: 91-99. 


\section{Abdel-Mobdy, A. E, Amall. Abdel-Mohsin, Aly, H. E and Abdel-.Rahim, E. A.}

التأثير المخفض للبن النوق على السمنة في الجرذان البيضاء الذكور

$$
\begin{aligned}
& \text { أحمد إمام عبد المبدئ (')ــ أمل إبراهيم عبد المحسن(r) }
\end{aligned}
$$

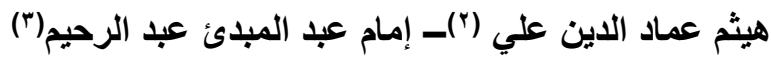

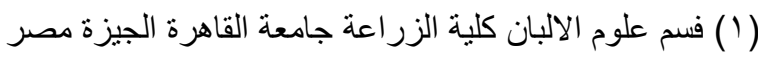

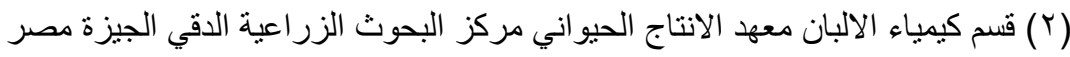

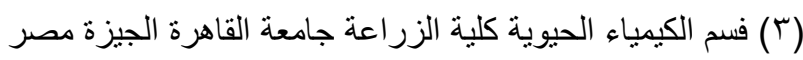

$$
\text { المستخلص العربي }
$$

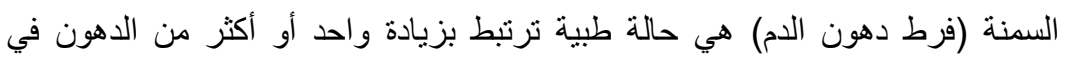

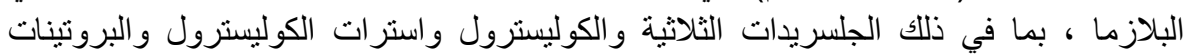

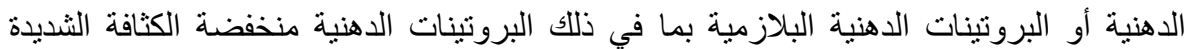

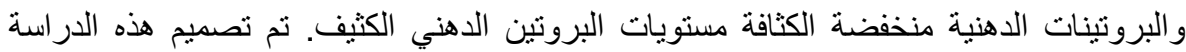
لاستكثاف كفاءة حليب النوق في السيطرة على ارتفاع نسبة الدهون في الدام. تم استخدام

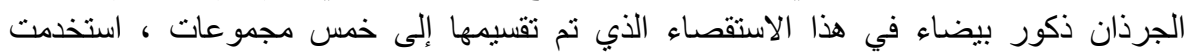

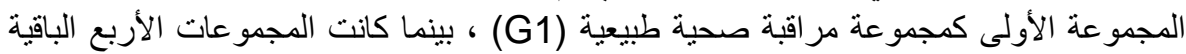

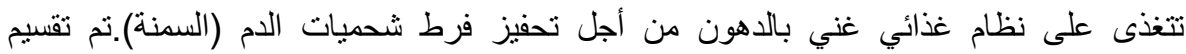

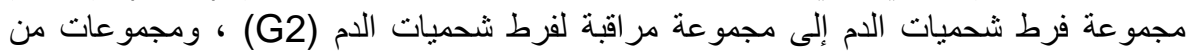

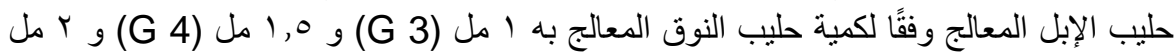

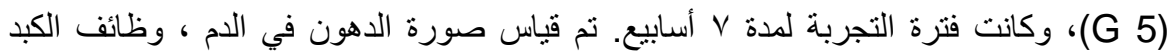

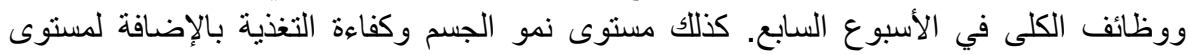
جلوكوز الدم ونشاط انزيم القلب (دي هيدروجينيز الإني حامض اللاكتيك) في الدم.

كثفت هذه الدراسة أن هناك انخفاض كبير في قياسات الدم من مجموعة السمنة المعالجة

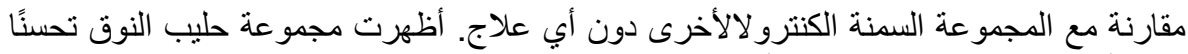

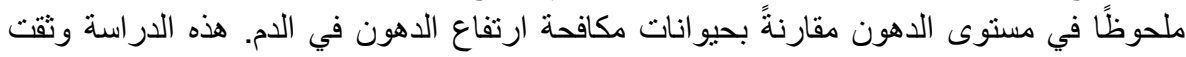

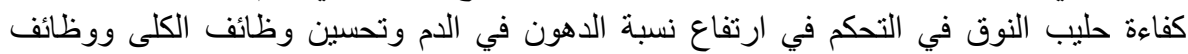

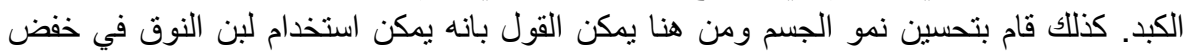

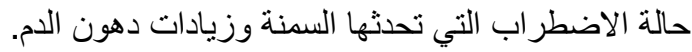

